塗膜のレオロジー

\section{Rheology of paint films}

UDC

$667.613: 532.135$

今 $\underset{\text { IMAI }}{\substack{\text { Takeo } \\ \text { 夫* }}}$

\section{1. むえがき}

塗膜の機械的諸性質はレオロジカルに取扱うことによ り正しくは握することができるが，一般のレオロジーに 対する関心は，一部の人達を除きむまり深くはないのが 現状である。これは工業面に叔ける実績に見るべきもの が少ないことにもよっているが，レオロジーの理論が難 解であるかのよ5に受け取られて，塗料を报ら人々から 敬遠されている面もあるのではないかと考える。たしか ルレオロジーには難解な面も岁るが, 物事をレオロジカ ルに見たり考えたりすることは誰でもできることであ り，かつ必要なことでもある。以下塗膜のレオロジーの 問題についていくつかの例を使用しながら解説すること にしたい。

\section{2.レオロジーとは}

レオトジー（rheology）とは物体（または物質）の変 形と流動に関する科学と定義されている。そしてここで 取扱われる対象物には主として粘弾性体が考えられてい る。粘弾性体というのは弾性的和よび粘性的な力学的挙 動を同時に示す物体のことで, 塗料执よび塗膜も粘弾性 体の中に包含される。したがってこれらの物体が変形も しくは流動する際のひずみと応力との関係は, 変形速度 によって大きく影響を受ける。すなわち上述のレオロジ カルに物事を考学るとらことは時間のファクターを考 慮に入れて考觉るといらことを意味している。レオロジ 一では上記の時間のファクターのことをいい表わすのに タイムスケールといらことばを使用している。タイムス ラールとはわかりやすくいえば測定に用いた時間を意味 していて，異なるタイムスケールで測定すると，塗膜の 機械的性質は全く異なっているように観測される場合が ある。このような場合, 塗膜が実用されているときのタ イムスケールとは異なるタイムスケールで塗膜の性質を 論じても意味がないことになるが，レオロジカルな考察

昭 41. 10. 13 受理

* 鉄道技術研究所

東京都国分寺市光町 2-180
を行なえばこのような䛊りを避けることができる。タイ ムスケールを变えて実験を行ならことは実際問題として は困難な場合が多いので，現実には温度を変えて実験す ることが多いが，このようにすることによっても同等の 効果を得ることができる。すなわちレオロジーには換算 変数法といらテクニックがあって，これによれば高い温 度で測定するということは長いタイムスケールで測定す るということと等価になり，実験の面では都合がよい が，反面加温することにより試料に変質を生じる場合は 使用できない欠点がある。いずれにせよレオロジーの議 論にのせるためには一点測定では不可で, 多点測定もし くは継続測定を行ならことが肝要でめり，一般の塗料試 験方法とはこの点で大きく相違している。レオロジーを 考光る際にはまたガラス転移点の問題高無視することが できない。現象論的レオロジーと分子論的な化学構造と の接触をこの点に見出すことができ，後述するいくつか の例もこの点に触れたものが多い。ガラス転移点とは物 質を構成している分子の運動状態に変化を生じる温度の ことで，したがって機械的性質もこの温度の近辺で大き な変化をする。ガラス転移温度についてはここでは詳し く述べないが，構成分子の構造との他を推測する上で有 効な指標となるものである。

レオロジーでは, 変形の際に和ける物体の弾性就よび 粘性の寄与の度合を解明することを目的としている。ひ ずみと応力との間に Hooke の法則が成立つことが見出 されたならば，その物体は純弾性体であって粘性的性質 は持ら合わせていない。他方, 変形の際の応力が变形速 度に正しく比例していたならば (Newton 流動), その 物体は純粘性的であって, 弾性的要素は存在していな い。しかし実在の塗膜は純弾性的でもなければ純粘性的 でもない。塗膜の応力ーひ-ずみ曲線を示すと図ー11)に示し たよらな形をしていて直線関係は得られない。すなわ方 直線からのずれの程度の大きいもの㴗ど粘性項の寄与の 度合が大きくなっていて, 長油性フタル酸樹脂塗膜の場 合には注ぼ横軸に平行した応力ーひずみ曲線が得られる。 このような塗膜の粘弾性を解明する目的で使用するレオ ロジカルな測定方法にはいくつかの方法があるが，いず 


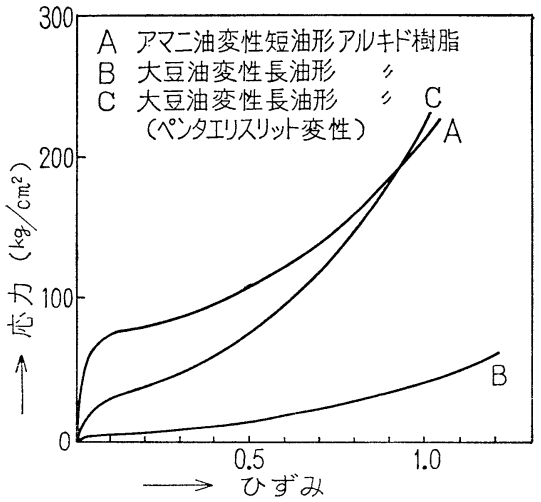

図-1 アルキド樹脂塗膜の応力ーひずみ曲線 れも結論的には塗膜の示す力学的挙動を弾性的部分と粘 性的部分とに分離して考察できる特徴を持つものである。

\section{3. 力学的模型と静的粘弾性}

粘性は物体が外水によて変形を行なら際には内部摩 擦として働き，その変形を妨げるような作用をする。た とえば粘弾性体にある一定の力を加えて引き伸ばして も，ただちにその外力に対応する大きさのひずみが生じ ないで，ある時間的経過を経たあとで最終的ひずみが達 成され\%。またひずみを生じている物体から外力を取除 いた場合のひずみ回復も同様な経過をたどって回復する。 このようなおくれ弾性を示す物体のことをフォークト物 体と呼び，それの示す力学的性質は図-2 の a に示した
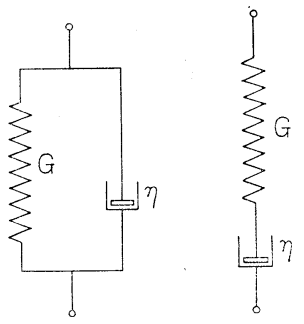

(a)フォークト模型

(b) マクスウエル模型

図-2 粘 弾 性 模 型

ような粘弾性模型でもって代表させることができる。図 のGはバネ (弾性要素), クは粘らゅうな液体で充満さ れた穴あさピストン（粘性要素）を表わしている。フォ 一クト物体のひずみ $\gamma$ と応力 $S$ との関係は

$$
S=\eta \frac{d \gamma}{d t}+G r
$$

のように書くことができ，乙たがってクリープ実験もし くはひずみ回復の実験を行なって，その際に観察された ひずみと応力との関係から試料の粘弾性常数 $G$ 和よび を決定することができる。
粘弾性体ではまた上記と異なった別種の力学的挙動が 観察されている。すなわちある物体に一定のひずみを与 えた場合の物体内の応力が時間と共に減少してゆく現象 (これを応力緩和と呼んでいる）であって，粘弾性体に 特有な現象であるが，これは上述したフォークト形の力 学的模型では説明することができない。この場合はバネ とピストンとを直列に結合した図-2 の b のような模形 （マクスウェル型の模型）を使用すると容易に理解する ことができる。すなわち最初バネによって受け持たれて いた応力はピストンが移動することにより次第に減少し てゆくと考觉ればよい。マクスウェル模型の力学的性質 は数式で示すと（2）のようになる。

$$
\frac{d r}{d t}=\frac{S}{\eta}+\frac{1}{G} \frac{d S}{d t}
$$

したがって応力緩和の実験からも塗膜の粘弾性常数を 決定することができる。ところでフォークト模型とマク スウェル模型とでは粘性と弾性との組合せの仕方が全く 異なっており，前者は応力緩和をしないはずであり，後 者では永久ひずみが残りひずみの回復は行なわないはず である。しかし実在の塗膜は応力緩和をすると同時にひ ずみ回復も行ない（図-3, 図-4 参照 $)^{2)}$, その力学的性

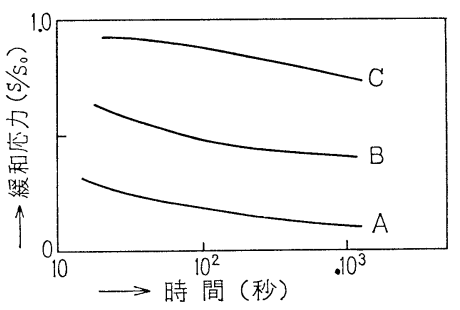

図-3 アルキド樹脂塗膜の応力緩和 (図中の $\mathrm{ABC}$ は図-1に同じ)

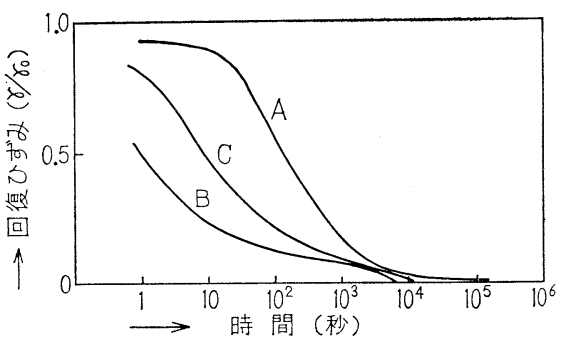

図-4 アルキド樹脂塗膜のひずみ回復 (図中の $\mathrm{ABC}$ は図-1 と同じ)

質を模型的に表現しようとすれば，要素の数を多数含も いわゆる一般化されたフォークト模型またはマクスウェ ル模型を使用する必要が生じてくる。一般化されたフォ ークト模型とマクスウェル模型との間では粘弾性常数間 の相互の転換が可能といわれている。フォークト模型の 
$\eta$ とGとの比のことを遅延時間, マクスウェル模型の $\eta$ とGとの比を緩和時間と呼んでいるが，したがって実在 の塗膜は数多くの遅延時間または緩和時間を含んでいる ことになる。ある塗膜の中に遅延時間または緩和時間が ぞのように分布しているかはクリープまたは応力緩和の 測定の結果から求めることができるが，塗料については この種の実験は汪とんど行なわれてはおらず，わずか に Snoddon ${ }^{3)}$ 女るいは Elleman ${ }^{4)}$ の報告を認める程度 である。これに対し塗膜の応力ーひずみ曲線を測定した 例は多い3,5,6,7)。乙かしここでもレオロジカルな結果の 解析は行なわれていない。引張り試験では大変形が生じ るので非線形領域の問題となり結果の解析が困難になっ ていることも一つの理由であるが，引張り試験は粘弾性 測定法というよりはむしろ工業的測定法というべきであ ろう。以上に述べたいくつかの測定方法はレオロジーで は静的測定法と呼ばれている方法であって, 塗膜粘弾性 测定の目的にはこれらの静的測定法よりも以下に述べる 動的測定法の方がはるかに多く使用されて和り，成果も 岁げている現状である。

\section{4. 塗膜の動的粘弾性}

物体に振動的な変形もしくは外力を与えて，そのとき に観測される力学的挙動から粘弾性を求める方法を動的 測定方法と呼えでいる。前に述べたように粘性は物体の 運動を抑制する作用を持っているため，物体が自由振動 を行なっている場合の振幅は，粘性に基づく内部摩擦の 影響で次第に減衰してゆき，また強制振動を行なわせた 場合は応力とひずみとの間に位相差が生じる。したがっ て前者の場合は振幅の対数減衰率を，また後者の実験で

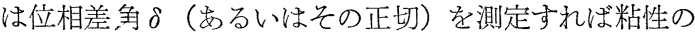
弾性に対する割合を知ることがでさる ${ }^{8)}$ 。動的測定方法 というのは一般に上記の原理を応用して測定する方法の ことである。応力をひずタで割った值を弾性率と呼んで いるが，動的測定の場合は応力とひずみの位相が一致し ないために弾性率の形は複雑になり, 複素数を用いる表 示が行なわれている。いま正弦的ひずみ（振幅 $\gamma_{0}$ ）を試 料に与えたとすると複素数平面上に括方る，応力振幅の

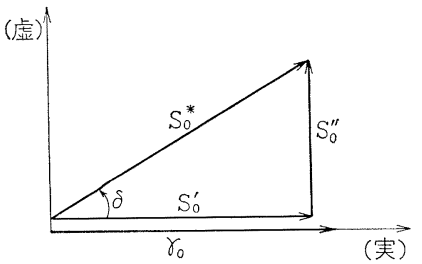

図-5 複素数平面上のひずみ振幅と応 力振幅との関係
ベクトルは図-5 に示したように $\delta$ だけ位相が進んで いる9)。この応力 $\left(S_{0}{ }^{*}\right)$ をひずみと同位相の成分 $S_{0}{ }^{\prime}$ と， これより位相が $90^{\circ}$ 進んだ成分 $S_{0}{ }^{\prime \prime}$ とに分解して，この ときの $S_{0}{ }^{\prime} / \gamma_{0}$ を動的弾性率 $\left(G^{\prime}\right), S_{0}{ }^{\prime \prime} / \gamma_{0}$ を損失弾性率 $\left(G^{\prime \prime}\right)$ と呼ぶ。図-2に示したフォークト模型およびマク スウェル模型を正弦的に変形させた場合の弾性率（動的 抢よび損失）と模型要素の粘弾性常数との関係はつぎの ようになる。

[フォークト模型の場合]

$$
\begin{aligned}
G^{\prime} & =G \\
G^{\prime \prime} & =\omega \eta
\end{aligned}
$$

[マックスウェル模型の場合]

$$
\begin{aligned}
G^{\prime} & =G \frac{\omega^{2} \tau^{2}}{1+\omega^{2} \tau^{2}} \\
G^{\prime \prime} & =G \frac{\omega \tau}{1+\omega^{2} \tau^{2}}
\end{aligned}
$$

ここで， $=\eta / G$ であり，木た $\omega$ は角振動率と呼ばれ る值で振動数に $2 \pi$ をかけたものを意味している。 $G^{\prime}$ の物理的意味は普通にいわれている弾性率と同じである が，G" は動的粘性率に $\omega$ をかけをの，すなわら試料 の粘性項の大きさを示す粘弾性関数である。をた $G^{\prime \prime}$ $G^{\prime}$ で割れば機械的な損失角正切すなわち $\tan \delta$ を得るこ とができる。

動的に求めた粘弾性測定結果が測定に使用したタイム スケール（ここでは $\omega ）$ の関数になっていることは(4) ～(6)式から容易に知ることができる。マクスウェル形 の粘弾性体について $G^{\prime}$ 抢よび $G^{\prime \prime}$ との $\omega$ と関係を図 示すると図-6 のようになり， $\omega \tau=1$ となる近辺で動的

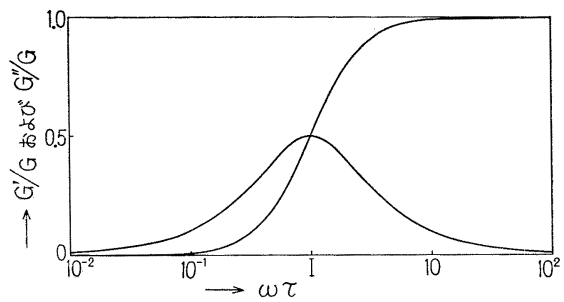

図-6 複素弾性率の周波数分散

弾性率は急変し，損失弾性率は極大を示す。このような 現象を粘弾性の周波数分散と呼び，フォークト粘弾性体 ではコンプライアンスに周波数分散が現われる。ての值 は温度が变わると変化するから測定周波数を一定にして, 温度による $G^{\prime}, G^{\prime \prime}$ の変化を求めると図-7 に示したよう に $\omega \tau=1$ の条件を満足する温度で $G^{\prime}$ の急变和よび $G^{\prime \prime}$ の極大が現われる。前にも述べたように実験的には周波 数を変えるよりも温度を変える方が容易なので，塗膜に ついての実験は温度分散を測定したものが多い。 


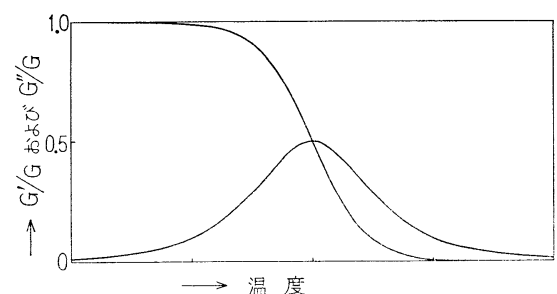

図-7 複素弾性率の温度分散

同一の試料でいくつかの温度分散が観察される場合が ある。最も高温で現われる分散を主分散または $\alpha$ 分散と 呼び，以下低温になるにしたがい， $\beta, \gamma, \cdots$ と名付けて いる。無定形高分子の $\alpha$ 分散は主鎖セグメントの緩和に 対応する分散でガラス転移点の近辺で生起する。 $\beta$ 分散 以下の副分散は主鎖以外の分子運動に帰属しているもの であって, 高橋 ${ }^{10}$ は油変性フェノール樹脂塗料について いくつかの副分散の存在を認めている。

以上に述べたように塗膜の温度分散を測定することに より塗膜の分子構造に関する知見を得ることができる が，工業面に括いても塗料品質改善のための有効な手掛 りとすることが可能である。すなおち主分散の生起する 温度は橋かけ構造 ${ }^{11)}$ や環構造 ${ }^{12)}$ の導入により上昇する

(図-8 参照)，女るいは分散の現れ方は共重合樹脂とブ

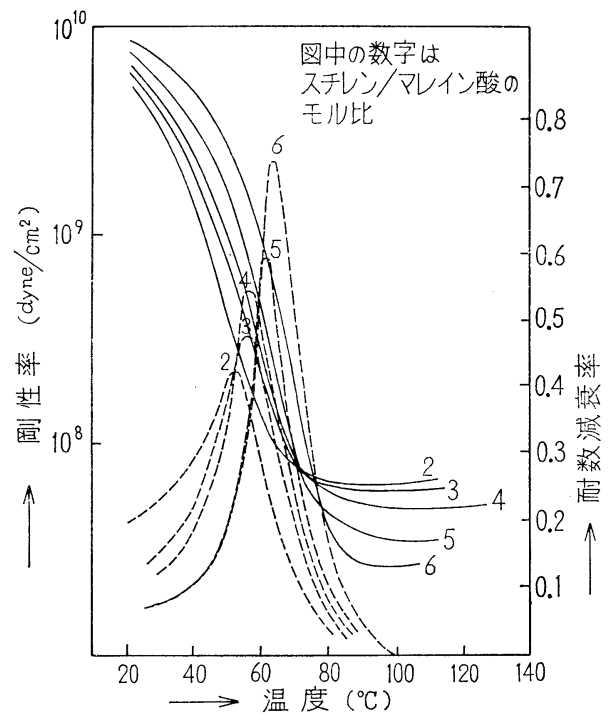

図-8＼cjkstart不飽和ポリエステル樹脂の剛性率および 対数減衰率の温度依存性 ${ }^{12)}$

レンドした樹脂とでは相違する13)などの事実や，顔料を

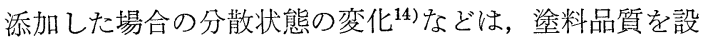
計する上での科学的根拠を提供するものである。低温に 特ける高分子固体の弾性率 (剛性率) はいずれも $10^{10}$ $10^{11} \mathrm{dyne} / \mathrm{cm}^{2}$ 程度を示しあまり変らないが，高温に拈
ける弾性率は膜の種類によって大きく異なっていて，橋 かけのない高分子では一方的に低下してゆくが，橋かけ 形高分子ではその橋かけの度合に応じてそれぞれに定め られた值をとる。ここで得られた弾性率は分子運動が自 由に行なわれる状態の下で示される弾性率, すなわらゴ ム弾性率であり，ゴム弾性の理論を応用することにより 橋かけ点間分子量を算定することがでさる。すなわら $E$ を高温でのヤング率， $M_{c}$ を橋か将点間の分子量， $M$ を 橋か以以前の一次分子の分子量， $\rho$ を密度とすると

$$
E=\frac{3 \rho R T}{M_{c}}\left(1-\frac{2 M_{c}}{M}\right)
$$

の関係が成立し， $M_{c}$ を求めることができる ${ }^{15)}$ 。

塗膜動的粘弾性の測定は自由放じり振動法和よび直読 式粘弾性測定装置を使用する10,13) 方法が用いられてい る。自由ねじり振動法は井上 ${ }^{16}$ により開発された測定方 法で，国内では多く使用されている方法でめるが，最近 では国外 ${ }^{17}$,18)でも使用されるようになっている。後者の 測定装置は試料の $\tan \delta$ を直接メーターに指示するよ5 に設計製作された試験機で市販されており，取扱いが容 易なので塗料以外の分野でも広く使われている。

\section{5. 䤰膜硬化過程のレオロジー}

塗膜の硬化過程に括ける粘弾性変化は適当な測定方法 を欠いていたため従来は取扱われたことがなかったが， 最近，著者は共振振動法を適用することにより本テーマ を究明するための手掛りを得ることがでさた ${ }^{19)}$ 。共振振 動法は振動リード法などとして知られているが，著者の 用いている測定法は試験片の両端を自由にして糸で懸垂 する方法である ${ }^{8)}$ 。試験片には鋼板を使用し，これに塗 料を塗装して共振振動数扣よび band width の時間的变 化を測定してゆけば，塗料の乾燥による動的弾性率招よ

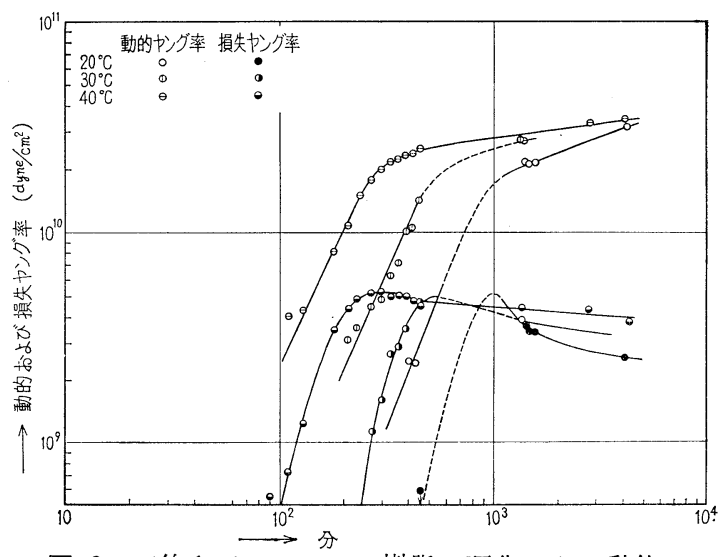

図-9 不飽和ポリエステル樹脂の硬化による動的 および損失弾性率の変化 
び損失弾性率の変化を追跡することができる。ただし本 測定法では乾燥の初期の段階に和ける粘弾性の変化は求 められないので, この点の解決方法について現在検討中 である。図-9 は本測定法により不飽和ポリエステル樹 脂塗料の硬化過程を測定した一例であるが，動的弾性率 は時間とともに単調に増大してゆくが，損失弾性率は極 大に達しためと減少してゆく状態が示されている。ここ で見られた損失弾性率の極大は，塗膜がこの時点におい て凍結域に入るすなわち, 乾燥過程下に抢ける塗膜のガ ラス転移温度が測定温度と等しくなった時点を指示して いるものと判断される。したがって塗膜の硬化過程を調 べるには損失弾性率すなわち粘性項の変化に着目するの が有利ではないかと想像された。

\section{6. む す び}

塗料とくに塗膜物性についてのレオロジカルな研究分 野では，わが国は諸外国に比較して一歩先んじているの ではないかと思う。これは故井上幸彦先生の大きな功績 と考えてよいが, 塗料物性研究会 10 周年に当たり, 今 後もこの優位を保ち続けるためになお一層の努力を我々 は払わなければならないことを深く感じた次第である。 前述したようにレオロジーは取り付きやすい学問ではな いが，塗膜物性を誤りなくは握するためにはぜひ必要で あり，塗膜の諸性質およびそれの背景になっている塗膜 構造についてのインフォーメーションをレオロジーを通 じて我々は入手することができる。大方のレオロジーに
対する関心が本稿により幾分なりとも深まるのであれば 大変幸せであると考觉る。

\section{文献}

1) 今井丈夫, 色材, 30, 216 (1957).

2）今井丈夫，鉄道技術研究報告 No. 329 (1962).

3) W. J. Snoddon, L. L. Carrick, Official Digest, 26, 195 (1954).

4) A. J.Elleman, W.D. May, J. Oil \& Colour Chemist's Assoc., 37, 595 (1954).

5) H. A. Nelson, Proc. Am. Soc. Testing Materials, 21, 1111 (1921).

6) H.W.Talen, FATIPEC $2^{\circ}$ Congr., 55 (1953).

7) R.M, Evans, Official Digest, 33, 970 (1961).

8）今井丈夫, 色材, 38, 80 (1965).

9) 中川鶴太郎, 神戸博太郎, “レオロジー”, p. 418, みすず書房 (昭 34).

10）高橋勇蔵，色材，38，483 (1965).

11）植木憲二，工化，65，137 (1962).

12）高橋誠一, 色材, 37, 155 (1964).

13）柴山恭一, 地大英毅, 第 12 回化学協学会連合講 演会, 昭和 41 年 10 月 8 日

14）佐藤弘三，色材，37，473 (1964).

15）井上幸彥, “塗料及び高分子”, p. 283, 誠文堂新 光社 (昭 38).

16）井上幸浐, 工化, 55, 262 (1952), 高化, 10, 140 (1953).

17) P.E. Pierce and R. M. Holsworth, J. Paint Tech., 38, 263 (1966).

18) Y.C.Chae, J. Paint Tech., 38, 285 (1966).

19）今井丈夫, 大川敏夫, 色材, 39, 383 (1966).

\section{色 材 協 会 誌 40 巻 1 号 (予 告)}

巻 頭 言

会誌の一層の充実を念願する…………………………………………桑 田勉

(当協会会長)

報文

水溶性樹脂塗料の電着塗装時にみられる各種無機イオンの

挙動について…………………………………田 慶一, 山崎不二雄, 草 野 肇

(日本油脂(株))

エポキシ化合物（第 11 報〜13 報）…………………田中 芳雄，村 田 稔外 2 名

(横浜国立大学工学部)

資料

溶剤の物理化学

目黒謙次郎，小石 真純

(東京理科大学)

文献 